\title{
Shari'ah Compliances Stock Market Integration: Evidence From Indonesia and Malaysia
}

\author{
Helma Malini ${ }^{1^{*}}$ \\ ${ }^{1}$ Tanjungpura University, Pontianak, Indonesia
}

\begin{abstract}
The nature of stock market integration has been an issue for almost a decade; this issue is more complicated toward Shari'ah compliance between countries since there are differences of companies screening process that can be classified as Shari'ah compliances. The differences make the integration of Shari'ah compliances stock market become a major issue in trying to answer the question whether one country can be the placed for Shari'ah portfolio diversification. This study aims to measure Shari'ah compliances integration and portfolio diversification in Indonesia and Malaysia Shari'ah compliances toward other Shari'ah compliances in the world. Six Shari'ah compliances are selected based on countries level of development and geographical factor. This studies relies on two major time series investigation techniques, namely the Auto-Regressive Distributed Lag (ARDL) approach and multi-variate Vector Error Correction Mechanism (VECM), based on the Generalized Methods of Moments (GMM). The ARDL approach is used to determine the existence of long run integration among Shari'ah compliances, while the multi-variate VECM based on the GMM is adopted to provide a robust analysis of short and long-run dynamic causal linkages among the stock markets.
\end{abstract}

Keywords: Efficient Market Hypothesis, Portfolio Diversification, Shari'ah compliances Integration

\section{INTRODUCTION}

Rapid growth of Indonesia and Malaysia Shari'ah compliances proves that Shari'ah compliances in both countries are not only potential for international hub of Shari'ah compliances but also a place for investor to diversified their portfolio rather than investing in domestic conventional stock market. The certainties of stability from listed companies that ensure by screening process make Shari'ah compliances establish in several countries in the world. However, the chances of diversifying portfolio from and to other Shari'ah compliances in the world is less due to the question whether Shari'ah compliances among countries are integrated to each other, in this case (Indonesia, Malaysia, India, Qatar, Bahrain and Japan).

The capability of Islamic financial industry to survive during crisis has make Shari'ah compliance becomes preferable choice for investor to diversify their investment portfolio. Malaysia, Egypt, Pakistan, Saudi Arabia and Sudan are pioneering countries for the development of Shari'ah compliances, while Indonesia, Middle East, Canada and US provide the platform and contribute to the

* Corresponding author. Email address: helma.malini@ekonomi.untan.ac.id 
diversification of Islamic capital market product. Despite, fundamental differences between Shari'ah and conventional capital markets, particularly in term of screening process, in the implementation, Shari'ah compliance can replicate useful and non contradictory functions of the conventional capital market as well.

However, with the rapid development of Islamic financial industry in the world particularly the Islamic capital market thus not attracts attention to research about Shari'ah compliances integration and portfolio diversification, while integration in Shari'ah compliances is essential to indicate the level efficiency and stock return behaviour of Shari'ah compliance. Therefore, the integration and portfolio diversification in Shari'ah compliance also as reflection of all available information and as such, are consistent with the economic fundamentals (Beechey et al., 2000). In the context of stock market integration, stock price in integrated markets have similar expected return due to the same risk exposure. Integrated Shari'ah compliance suggesting that these markets offer no diversification benefits as the market performance tend to be similar. In a risk-return framework, investor can increase return or reduce risk or both, by having investment mix in Shari'ah compliance which return are uncorrelated. Thus, the degree of stock market integration suggests the potential portfolio diversification benefits that can be gained by investor.

\section{LITERATURE REVIEW}

Integration is one the objective in forming Shari'ah compliance that described in the solidarity and brotherhood in Islam. Chapra (2001) asserted that the apparent disparities in terms of nationality, race, creed and color are artificial and have no place in Islam. The holy Quran dearly points that human beings were created as one nation (ummah) but become divided because of their differences ( $\mathrm{Al}$ Quran 10; 19), Although the integration of economy is the foundation of Shari'ah economic system, but in the implementation the integration among Shari'ah compliance is in question due to several differences of Islamic economic system that implemented in several countries.

Furthermore, one country that has open foreign investment policy will benefit from the integration of stock market, since the level of stock market integration will influence the level of benefits or profit of international investment, moreover stock market integration between countries has important consequences in terms of stock return predictability, portfolio diversification, asset allocation, economics of scale and scope and long term gain (Kim and Singal, 2000; Goetzman et al 2005; Mc Andrews and Stefanadis, 2002; Artige and Nicolini, 2006; Syllignakis and Kouretas, 2011). The benefit of stock market integration between countries is the capability to decrease the cost of capital, increased the investment opportunity set for local and foreign investor but also lead to significant welfare gains from higher saving and international risk sharing or diversification through the possibility of integration.

In minimizing risk and increasing profit opportunities, more investor seeks to diversify their portfolio to international territory. International portfolio makes it possible to expand the efficient frontier and reducing the systematic risk below domestic securities. Ming Yuan (2007) have studied the benefits of international diversification and one of the benefits is to expand the efficient frontier and reduce the systematic risk level below that of domestic securities alone. The reason is that 
structural and cyclical differences across economies makes the risk-reduction benefit possible. If one market is doing worse than expected it is likely that another market will do better than the expectations, hence the risk is reduced and losses are offsets.

Hussin et al. (2013) empirically investigates co-integration between Islamic stock market in Malaysia, Indonesia and the world by applying the Vector Auto Regression (VAR) method. The research used monthly data from January 2007 to May 2012 taken from authorized sources. The finding shows that there is no longrun or equilibrium relationship exists between FTSE Bursa Malaysia Emas Shari'ah (FBMES), Jakarta Islamic Index (JAKISL), and Dow Jones Islamic Market index (DJIM). Conclusion can be made that the Islamic stock markets of Malaysia does not integrate with Indonesia's, as well as with the world markets in the long run, the result also showed that Malaysia is a favorable country for investor to diversify their investment.

Despite there have been numerous studies examining market integration among developed and emerging markets, but there have been relatively few studies explore the issue of stock market integration and portfolio diversification in Islamic stock market particularly in Shari'ah compliance. For example, Kassim (2010) confirmed that even though the growth of Indonesia and Malaysia Shari'ah compliances has been increasing in term of size, number of listed companies and number of investor. However no empirical studies on whether Shari'ah compliances in Indonesia and Malaysia integrated with Shari'ah compliances in the selected Shari'ah compliances.

\section{RESEARCH METHODOLOGY}

\section{Data}

In analyzing the nature of integration among the Shari'ah compliances, six Shari'ah compliances are chosen to be included in the analysis. Data on daily closing stock indices of the six Shari'ah compliances are gathered from Thomson data stream database covering the period since January 2000 to December 2010. The Shari'ah compliances and their respective indices being selected are as follows:

Table 1 Selected Country for Shari'ah Compliances Integration

\begin{tabular}{llc}
\hline \multicolumn{1}{c}{ Country } & \multicolumn{1}{c}{ Indices } & $\begin{array}{c}\text { Number of Listed } \\
\text { Companies }\end{array}$ \\
\hline Indonesia (ID) & $\begin{array}{l}\text { Indonesia Shari'ah Compliance (ISC) } \\
\text { Malaysia (MY) }\end{array}$ & 234 \\
& $\begin{array}{l}\text { Kuala Lumpur Shari'ah Compliance } \\
\text { (KLSI) }\end{array}$ & 854 \\
Bahrain (BH) & Bahrain Stock Exchange & 50 \\
Qatar (QR) & Dubai Stock Exchange & 55 \\
Japan (JAP) & Japan FTSE Shari'ah Compliance & 100 \\
India (IND) & India Shari'ah Compliance & 50 \\
\hline
\end{tabular}

The selection of this stock market is based on the reason that six Shari'ah compliances cover a wide geographical which contributes to the objectives of this study. In particular, the selected Shari'ah compliances represent six major Shari'ah 
compliances across the globe, not only in term of market capitalization but also with number of listed companies.

\section{Methodology}

\section{ARDL Bound Testing Approach}

To examine the long run relationship among the Shari'ah compliances, this research employs the ARDL bound testing approach to co integration which involves estimating the conditional error correction version of the ARDL model (Pesaran et al. 2006). The choice of ARDL approach in this research is based on the consideration of co integration analysis are unbiased and efficient given the fact that, firstly, it can be applied to a small sample size study and therefore conducting bound testing will be appropriate for the present study, secondly it estimates the short and long run components of the model simultaneously, removing problems associated with omitted variables and autocorrelation. Finally, it can distinguish between dependent and independent variable.

In this study, the estimation following baseline model:

$$
\begin{aligned}
& I N A t=\alpha 0+\alpha I M Y t+\alpha 2 I N D t+\alpha 3 Q R t+\alpha 4 J A P t+\alpha 5 B H t+\epsilon t \\
& M Y t=\alpha 0+\alpha I I N A t+\alpha 2 I N D t+\alpha 3 Q R t+\alpha 4 J A P t+\alpha 5 B H t+\epsilon t
\end{aligned}
$$

Where INA, MY, IND, QR, JAP, BH refer to the Shari'ah compliances of Indonesia, Malaysia, India, Qatar, Japan, and Bahrain, respectively, and $\ell t$ is the error term for the model. The error correction version of the ARDL framework pertaining to equation can be reproduced as follows;

$$
\begin{aligned}
& \Delta \mathrm{INA} t=\delta 0+\sum_{i=1}^{p} \sum_{\varepsilon i \Delta I N A t-1+{ }_{i=1}^{p}} \sum_{\phi i \Delta M Y t-i}^{p} \sum_{i=1}^{p} \sum_{i=1}^{p} \\
& \begin{array}{c}
\sum_{i=1}^{p} \sum_{\mu i \Delta J A P t-i+}^{p}{ }_{i=1}^{V i \Delta B H t-i+\lambda I \mathrm{INA} t-1+\lambda 2 M Y t-1} \\
+\lambda 3 \mathrm{IND} t-1+\lambda 4 \mathrm{QR} t-1+\lambda 5 J A P t-1+\lambda 6 B H t-1+u 1 t
\end{array}
\end{aligned}
$$$$
\Delta \mathrm{MY} t=\delta 0+\sum_{i=1}^{p} \sum_{\varepsilon i \Delta M Y t-1+{ }_{i=1}^{p}} \sum_{\phi i \Delta I N A t-i}^{p} \sum_{i=1}^{p} \sum_{\phi i \Delta I N D t-i+1}^{p}
$$

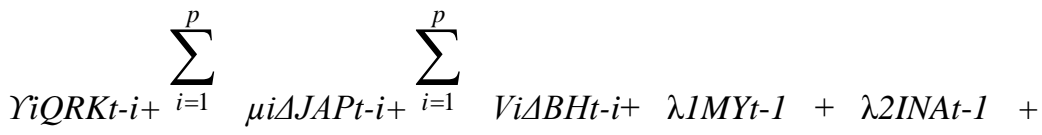$$
\lambda 3 I N D t-1+\lambda 4 Q R t-1+\lambda 5 J A P t-1+\lambda 6 B H t-1+u 1 t
$$ 
In the above equation, the terms with the summation signs represent the error correction dynamic while the second part (term with $\lambda s$ ) correspond to the long run relationship. The null of no co integration in the long run relationship is defined by $H 0: \lambda 1=\lambda 2=\lambda 3=\lambda 4=\lambda 5=0$ is tested against the alternative of $H 1: \lambda 1 \neq \lambda 2 \neq \lambda 3$ $\neq \lambda 4 \neq \lambda 5 \neq 0$, by the means of familiar $F$-test. However, the asymptotic distribution of this $F$-statistic is non-standard irrespective of whether the variables are I ( 0$)$ or I (1). Pesaran et al (2006) have tabulated two sets of appropriate critical values. One set assumes all variables are I(1) and another assumes that they are all $\mathrm{I}(0)$. This provides a bound covering all possible classifications of the variables into I(1) and (I) 0 or even fractionally integrated. If the $F$-statistic lies above the upper bound level, then the null are rejected, this indicates the existence of co integration. While if the $F$-Statistic falls below the bound level, the null cannot be rejected, which supporting no co integration exist. If, however, it falls within the band, the result is inconclusive.

Finally, in order to determine the optimal lag-length incorporated into the model and to select the ARDL model to be estimated, the study employs the Akaike (1974) Information Criterion (AIC) with the maximum lag-length to be considered as 8.

\section{Generalized Method of Moments}

This research investigates the short and long run relationshiop among six selected Shari'ah compliances worldwide. The research estimates them by GMM estimation, where the error correction terms are incorporated in the models. The GMM can be used to estimate the model parameters and test the set of moment conditions that arise during period of research. Based on Hung and Cheung's (1995) study on five variables Johansen-Juselius cointegration test, the VECM representation can then be reformulated in a simple matrix form as follows :

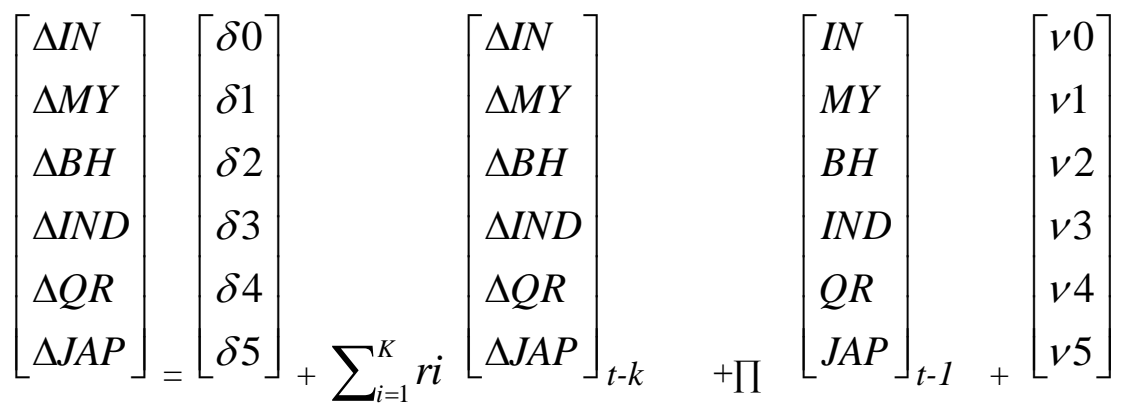

In this research, the akaike (1974) information criterion (AIC) is used to determine the lag length incorporation in the entire tests of this research. It is important to note that for GMM estimator to be identified; there must be at least as many instrumental variables $\mathrm{Z}$ as there are parameters $\theta$. Following Lee et al (1997), this study used lags of explanatory variables as the instrumental variables. This variables were opted for use because of the difficulty in finding other instrument variables, as the research utilizes daily data and for an extended period. These variables are, however, obvious instrument and in most cases, should be included in the instrumental list. Another important aspects of specifying GMM is the choice of the weighting matrix to yield a consistent and robust estimate. 


\section{FINDING AND DISCUSSION}

The descriptive analysis provides preliminary description of the nature and volatility of selected Shari'ah compliances. At the same time, it enables comparison of the basic performance indicators of the stock indices allowing an observation of how they fare against each other.

Table 2 Descriptive Statistics of Selected Shari'ah Compliances

\begin{tabular}{ccccccc}
\hline Statistics & ID & MY & IND & QR & BH & JAP \\
\hline Mean & 0.1411 & 0.3872 & 0.0004 & 0.0003 & 0.0007 & 0.0001 \\
Median & 0.4500 & 0.3700 & 0.0089 & 0.0033 & 0.0002 & 0.0064 \\
Maximum & 0.4900 & 0.4800 & 0.0617 & 0.0833 & 0.0485 & 0.0835 \\
Minimum & 0.0956 & 0.3300 & 0.6176 & -0.0061 & -0.0158 & -0.0109 \\
Std Deviation & 0.0426 & 0.9224 & 0.0403 & 0.0226 & 0.0111 & 0.0300 \\
Skewness & 0.0206 & 0.8608 & -0.6438 & -0.6711 & -0.4949 & -0.9972 \\
Kurtosis & 2.3836 & 3.0325 & 0.2373 & 3.1044 & 2.07115 & 3.8300 \\
\hline
\end{tabular}

Table 2 provides a summary statistic of the stock return for the selected Shari'ah compliances in this study. In term of highest average daily return, Malaysia is showing the highest average daily return 0.38 percent, followed by Indonesia at 0.14 percent, Bahrain 0.07 percent, India and Qatar at 0.04 and 0.03 percent and Japan at 0.01 percent. In terms of volatility of return as reflected by the standard deviation, Malaysia is the highest Shari'ah compliance risk at 0.92, Followed by Indonesia Shari' ah compliance at 0.04 . India and Bahrain compliance offer the lowest risk at 0.01 percent. Regarding the measurement of skewness ${ }^{1}$, India, Qatar, Bahrain and Japan Shari'ah compliances exhibit negative skewness.

In conclusion, Shari'ah compliances that have the highest volatility are Shari'ah compliance in emerging and developing markets; Malaysia and Indonesia. The volatility of Malaysia Shari'ah compliance can be explained as the result of diversified companies background and enormous product diversification in Kuala Lumpur Shari'ah compliance, resulting to the chance of gaining benefit from portfolio diversification toward implementing buying and selling different company's strategy (Pandian and Jayanthi, 2009). While, the volatility of Indonesia Shari'ah compliance can be explained as investor response due to lack of information about Shari'ah compliance in Indonesia. Lack of information can be in term of screening process information, company's background and types of product from companies that listed as Shari'ah compliances.

Table 3 Correlations among Shari'ah Compliances Stock returns

\begin{tabular}{llllll} 
ID & MY & BH & IND & QR & JAP \\
\hline
\end{tabular}

\begin{tabular}{cccccccc} 
ID & 1.000 & & & & & \\
MY & 0.430 & 1.000 & & & & \\
BH & 0.312 & 0.341 & 1.000 & & & \\
IND & 0.241 & 0.453 & 0.031 & 1.000 & & \\
QR & -0.222 & -0.456 & 0.674 & -0.765 & 1.000 & \\
JAP & 0.431 & 0.789 & 0.563 & 0.876 & 0.765 & 1.000 \\
\hline
\end{tabular}

${ }^{1}$ Skewness is a measurement of asymmetry shape in a time series data distribution 
Table 3 report that during period of observation, the selected Shari'ah compliances showed strong correlation to each other as reflected by strong correlation of coefficients among the Shari'ah compliances. Strong correlation or highest value of correlation is recorded between India and Japan (0.876), followed by Malaysia and Japan (0.789) and Qatar and Japan (0.765). Strong correlation between these Shari'ah compliances suggest that the major factor contributing to the strong correlation which is economic grouping and geographical closeness do not apply in this research, since the countries that correlated to each other are came from different region, between Asian and Middle East or between developed and developing countries. Furthermore, this part of research does not find any correlation or weak correlation between Asian to Asian Shari'ah compliances, which also similar to the previous study about Asian stock market integration (Gupta and Guidi, 2012).

Japan Shari'ah compliance showed strong correlation with other selected Shari'ah compliances in this research, although Japan Shari'ah compliance considered as relatively new, but the country has strong bilateral trades among selected countries and resulting to the interdependence between Shari'ah compliances very strong. The rest of the Shari'ah compliances also showed strong correlation, except for Bahrain and Indonesia with value lesser than 0.1. While Indonesia and Qatar, Malaysia and Qatar showed weakest correlation with negative ${ }^{2}$ value of correlation.

Diversification benefits in several Shari'ah compliances countries imply that the countries are very liquid, investor are easily moving their funds to Shari'ah compliances in the country, and resulting to the chances of making speculative action very high. Specifically the country that having the weakest correlation is: Bahrain-Qatar ${ }^{3}$ (0.031), Indonesia-Qatar (-0.222), Malaysia and Qatar (-0.456). Bahrain and Qatar Shari'ah compliances are among the country that has the weakest correlation to other Shari'ah compliances. Weak economic interdependence can be the reason for the low correlation of Indonesia and Malaysia Shari'ah compliances to other Shari'ah compliances in Middle East. Furthermore, due to the policy of closed stock market for foreign investor to invest in most of the stock market in Middle East, making the correlation between Bahrain and Qatar as one of the country in Middle East remained weak. As for Indonesia and Malaysia Shari'ah compliances, both countries showed high correlation to each other with value of (0.430) although not as strong as India and Japan. The correlation between Indonesia and Malaysia due to close proximity, makes investor in both countries have the flexibility in term of liquidity, they tend to move and switch their investment between Shari'ah compliances or to conventional stock market.

\footnotetext{
2 A negative correlation which is displaying the correlation coefficient between 0 and -1 indicates that there are two securities move in the opposite direction.

${ }^{3}$ The weak correlation between Bahrain and Qatar also can be explained by relating to closed stock market policy that implemented in several countries in Middle East, although Bahrain and Qatar are geographically closed to each other, the impact of the policy remain to the integration of stock market among countries in Middle East.
} 
Table 4 ARDL- F Statistic For Testing Existence of Co-Integration

\begin{tabular}{cccccc}
\hline $\begin{array}{c}\text { Order } \\
\text { of Lag }\end{array}$ & $\begin{array}{c}\text { Model 1 } \\
\text { (INA, MAL) }\end{array}$ & $\begin{array}{c}\text { Model 2 } \\
\text { (IND, QR, } \\
\text { BH, JAP) }\end{array}$ & $\begin{array}{c}\text { Model 3 } \\
\text { (INA, IND, } \\
\text { QR, BH, } \\
\text { JAP) }\end{array}$ & $\begin{array}{c}\text { Model 4 } \\
\text { (MAL, } \\
\text { IND, QR, } \\
\text { BH, JAP) }\end{array}$ & $\begin{array}{c}\text { Model 5 } \\
\text { (INA, } \\
\text { MAL, IND, } \\
\text { QR, BH, } \\
\text { JAP) }\end{array}$ \\
\hline 1 & 1.217 & 2.117 & 1.9832 & 2.7652 & 0.2728 \\
2 & 1.224 & 2.445 & 1.6322 & 2.7699 & 0.9823 \\
3 & 1.321 & 2.321 & 1.6543 & 1.9202 & 0.7288 \\
4 & 2.1150 & 3.431 & 2.6548 & 3.92829 & 0.6754 \\
5 & 4.321 & 3.011 & 2.8903 & 1.90231 & 0.5632 \\
6 & 1.321 & 3.221 & 2.9783 & 1.08299 & 0.7654 \\
\hline
\end{tabular}

Notes: The relevant critical value bounds are taken from Pesaran (2001): (i). Case iii: unrestricted intercept and no trend (number of regressors $=7$ ), they are $2.96-4.26$ at the $99 \% ; 2.32-3.50$ at the $95 \%$; and $2.03-3.13$ at the $90 \%$ significance levels respectively; and (ii) Case v: unrestricted intercept and unrestricted trend (number of regressors $=7$ ), they are $3.34-4.63$ at the $99 \%$; 2.69 383 at the 95\%; and $2.38-3.45$ at the $90 \%$ significance levels respectively. * denotes that F-statistics falls above the $90 \%$ upper bound.

The ARDL analysis determines the existence of long run equilibrium relationship among Shari'ah compliances. Statistically, two market or more are integrated to each other if the markets share a long run equilibrium relation between two variables (Yusof and Majid, 2006). For Shari'ah compliances, the concept of Shari'ah stock price that moves together in long run is a result of arbitrage activity. Arbitrage in Shari'ah principle is prohibited, since this action is a form of taking advantages from other party weaknesses and in Shari'ah it is considered as ihtikar. The existence of common long term trend in Shari'ah compliances can be empirically proven by the significant joint $\mathrm{F}$ - Statistics produced by the estimated equation. Table 4 showed the result of ARDL test for the existence of long run cointegration among selected Shari'ah compliances. Indonesia and Malaysia showed weak co-integration (90 percent significant level) at lag length 1, suggesting that there is a long run equilibrium relationship between the two Shari'ah compliances. Shari'ah compliances in model 2 (India, Qatar, Bahrain, and Japan) also showed long run equilibrium. When Indonesia and Malaysia Shari'ah compliances are concluded in the model (Model 3 and 4) there are also significant evidences of long run relationship among the Shari'ah compliances. However, when both Indonesia and Malaysia are included and link to the whole selected Shari'ah compliances (Model 5) this market found to be not significant and not co-integrated to each other.

Long run equilibrium among selected Shari'ah compliances exist if the selected country remove institutional Shari'ah constraint that consist of taxation, foreign exchange controls, capital market regulations, transaction costs and socializing foreign markets to investor (Bartram \& Dufey, 2001). Institutional constraint for Indonesia Shari'ah compliance is in form of lowering tax ${ }^{4}$ for foreign

\footnotetext{
${ }^{4}$ Indonesia in general is not applying foreign exchange control. Accordingly, Indonesia becomes more favorable to be an investment destination in the perspective of less exchange control barriers.
} 
investor, transparent Shari'ah compliance regulations, lowering transaction cost such as brokerage fee and increasing liquidity. While, the institutional constraint For Malaysia Shari'ah compliance is lowering taxes for foreign investor and open market policy to attract more foreign investor.

Table 5 Result of Multivariate VECM Analysis (Model: ID, MY, IND, BH, $\mathrm{QR}, \mathrm{JP})$

\begin{tabular}{|c|c|c|c|c|c|c|c|c|}
\hline \multirow{2}{*}{$\begin{array}{c}\text { Dpdt } \\
\text { Variablet }\end{array}$} & \multicolumn{4}{|c|}{$\begin{array}{c}\text { Independent Variables } \\
\text { [F-stats] }\end{array}$} & \multicolumn{2}{|c|}{$\begin{array}{l}\text { (t-stats) } \\
\text { ECT } t-1\end{array}$} & \multicolumn{2}{|c|}{ Diagnostic Test } \\
\hline & $\Delta$ ID & $\Delta \mathbf{M Y}$ & $\Delta$ IND & $\Delta \mathbf{B H}$ & $\Delta \mathbf{Q R}$ & $\Delta \mathbf{J P}$ & & \\
\hline$\Delta \mathrm{ID}$ & - & $\begin{array}{c}6.202 * * * \\
{[0.000]}\end{array}$ & $\begin{array}{c}0.543 \\
{[0.169]}\end{array}$ & $\begin{array}{c}4.432 * * * \\
{[0.007]}\end{array}$ & $\begin{array}{c}4.985 * * * \\
{[0.001]}\end{array}$ & $\begin{array}{c}5.981 * * * \\
{[0.001]}\end{array}$ & $\begin{array}{c}-0.948 * * * \\
(-4.386)\end{array}$ & $\begin{array}{c}\mathrm{R}^{2} \mathrm{adj}=0.24 \\
\mathrm{DW}=1.43 \\
\mathrm{~J} \text {-stats }=0.03\end{array}$ \\
\hline$\Delta \mathrm{MY}$ & $\begin{array}{c}11.342 * * * \\
{[0.000]}\end{array}$ & - & $\begin{array}{l}1.645^{* *} * \\
{[0.021]}\end{array}$ & $\begin{array}{l}1.984 * * \\
{[0.064]}\end{array}$ & $\begin{array}{c}0.542 \\
{[0.0876]}\end{array}$ & $\begin{array}{c}1.986 \\
{[0.032]}\end{array}$ & $\begin{array}{c}-0.643 * * * \\
(-3.002)\end{array}$ & $\begin{array}{c}\mathrm{R}^{2} \mathrm{adj}=0.24 \\
\mathrm{DW}=1.22 \\
\mathrm{~J} \text {-stats }=0.02\end{array}$ \\
\hline$\Delta \mathrm{IND}$ & $\begin{array}{c}0.643 \\
{[0.218]}\end{array}$ & $\begin{array}{l}3.654^{*} \\
{[0.032]}\end{array}$ & - & $\begin{array}{c}2.532 * * \\
{[0.010]}\end{array}$ & $\begin{array}{c}1.512 \\
{[0.414]}\end{array}$ & $\begin{array}{l}1.567 * \\
{[0.023]}\end{array}$ & $\begin{array}{c}-0.598^{* * *} * \\
(0.203)\end{array}$ & $\begin{array}{c}\mathrm{R}^{2} \mathrm{adj}=0.03 \\
\mathrm{DW}=1.77 \\
\mathrm{~J} \text {-stats }=0.32\end{array}$ \\
\hline$\Delta \mathrm{BH}$ & $\begin{array}{c}0.543 \\
{[0.142]}\end{array}$ & $\begin{array}{c}1.543 \\
{[-0.232]}\end{array}$ & $\begin{array}{l}2.121 * * \\
{[0.023]}\end{array}$ & - & $\begin{array}{c}0.765 \\
{[0.454]}\end{array}$ & $\begin{array}{c}0.432 \\
{[0.126]}\end{array}$ & $\begin{array}{c}-0.988 * * * \\
(1.113)\end{array}$ & $\begin{array}{c}\mathrm{R}^{2} \mathrm{adj}=0.03 \\
\mathrm{DW}=0.67 \\
\mathrm{~J} \text {-stats }=0.21\end{array}$ \\
\hline$\Delta \mathrm{QR}$ & $\begin{array}{c}2.432 \\
{[0.333]}\end{array}$ & $\begin{array}{l}3.432 * \\
{[0.001]}\end{array}$ & $\begin{array}{c}2.5346^{*} \\
* \\
{[0.001]}\end{array}$ & $\begin{array}{c}3.754 * * \\
{[0.000]}\end{array}$ & - & $\begin{array}{l}1.332 * * \\
{[0.001]}\end{array}$ & $\begin{array}{c}- \\
0.7543 * * * \\
(-6.675)\end{array}$ & $\begin{aligned} \mathrm{R}^{2} \mathrm{adj} & =0.043 \\
\mathrm{DW} & =1.23 \\
\mathrm{~J}-\mathrm{stats} & =0.34\end{aligned}$ \\
\hline$\Delta \mathrm{JP}$ & $\begin{array}{c}3.432 * * * \\
{[0.001]}\end{array}$ & $\begin{array}{c}2.642 * * \\
{[0.001]}\end{array}$ & $\begin{array}{c}2.732 \\
{[0.006]}\end{array}$ & $\begin{array}{c}2.785 \\
{[0.312]}\end{array}$ & $\begin{array}{c}0.564 \\
{[0.000]}\end{array}$ & $\begin{array}{c}1.765 \\
{[0.001]}\end{array}$ & $\begin{array}{c}- \\
0.8743 * * * \\
(-3.253)\end{array}$ & $\begin{array}{c}\mathrm{R}^{2} \mathrm{adj}=0.043 \\
\mathrm{DW}=0.32 \\
\mathrm{~J} \text {-stats }=0.23\end{array}$ \\
\hline
\end{tabular}

Notes: $* * *, * *$ and $*$ represent significance at the $1 \%, 5 \%$ and $10 \%$ level, respectively. ECT t- ${ }^{-1}$ is derived by normalizing the co integrating vectors on the dependent variable, producing residual $r$. by imposing restrictions on the coefficients of each variable and conducting wald test, we obtain F-statistics for each coefficients in all equations. Figures in the (.) and [.] represents $t$-statistics and probabilities for $F$-statistics, respectively. The optimal lag-length included in the models is based on the Akaike Information criteria (AIC). DW is durbin watson $d$ test for autocorrelation and J-stats is the Hansen's J-Statistics test for correct specification (over identifying restrictions) of the model. Lag length is set at 3 .

The Vector Error Correction Model (VECM) based on the GMM estimation for the selected Shariah compliances is appropriate technique because this model distinguishes between short and long run dynamics linkages among Shari'ah compliances. Both short and long run linkages are important to see the impact of regulation and Shari'ah compliance stock price toward each other in selected Shari'ah compliances. The existence of the short run multivariate Granger Causalities among Shari'ah compliances indicated by significance of the Fstatistics through joint test of lagged differences, while the long-run is shown by the significance of the t-statistics test ECT. The VECM analysis is conducted on the baseline model containing all six Shari'ah compliances. 
The result showed that all the Error Correction Terms (ECTs) are significant for the Shari'ah compliances being reviewed. The ECTs coefficients ranging from 0.59 to 0.98 suggest that on average, the selected Shari'ah compliances takes nearly about one and half week to clear any disequilibrium. Disequilibrium in Shari'ah compliances also considered as distraction for the stability of Shari'ah compliances stock price, since it can trigger volatility from in balancing situation.

Indonesia Shari'ah compliance, in term of short run causalities is significantly influenced by Malaysia, Qatar and Japan Shari'ah compliances, while the influence of India and Bahrain is weak. Malaysia Shari'ah compliance, in term of short run causalities is significantly influenced by India and Qatar Shari'ah compliances, while other Shari'ah compliances in the study showed weak influences to Malaysia Shari'ah compliance. While, Indonesia Shari'ah compliance gives a strong influence to the Malaysia and Japan Shari'ah compliance and Malaysia Shari'ah compliance gives a strong influence to the Indonesia Shari'ah compliance, while to others Shari'ah compliances, the influence somewhat very weak.

\section{CONCLUSION}

The nature of integration ${ }^{5}$ among stock markets conveys important information for effective market diversification. First integration of the stock market essentially indicates the efficiency of the financial markets. According to the Efficient Market Hypothesis (EMH), integrated stock market is characterized by its ability to adjust rapidly to new information (Fama et al, 1969). Therefore, price of assets in efficient financial markets as fully reflective of all the available information and as such, are consistent with the economic fundamental (Beechey, et al, 2000). In efficient stock market, generally, stock market integration would increase, since the movement of information between countries is higher due to the elimination of barrier such as prohibition of investing for foreign investor or improvement of trading facility.

In the implementation, fully integrated Shari'ah compliances is not prohibit investor for having their fund place in a securities in Shari'ah compliances around the world, since investor always seeking for portfolio that gives higher return and lower risk, while the chance for having the exposure are quite minimal in their own countries, thus placing fund in other foreign countries are best preferences. In addition, the gains from international portfolio diversification appear to be largest for countries with high country risk, since Indonesia is a country with high profile risk, thus making other differences across countries, such as size of the stock market, size of the banking sector, and trade openness do not support to explain differences in the gains from international portfolio. For Indonesia that considered as a country with a high risk profile makes the growth of Shari'ah compliance becomes dependable to the volatility of risk. Risk in Shari'ah or generally stated with Gharar which can be interpreted as doubtful toward certain things. Relates with risk term in stock market that covered with uncertainty, volatility or loss that

\footnotetext{
${ }^{5}$ It is worth noting that greater market integration does not necessarily go hand in hand with higher market efficiency. Lence and Falk (2005) illustrate within the setting of a standard dynamic general equilibrium asset-pricing model that these two important concepts are independent of one another.
} 
accepted by investor makes Shari'ah principle becoming less integrated with the conventional system, thus eventually influence the integration of Shari'ah compliances among countries.

The implication of this research for investor to invest in selected Shariah compliance is that there are still huge potential benefits of international portfolio diversification across these countries. In term of their correlation coefficient, Indonesia and Malaysia is emerge and become a considerable portfolio diversification for them, but India, Japan, Bahrain and Qatar also attract foreign investor to diversified their portfolio, although selected countries provide huge risk but also provide huge return.

\section{References}

Akaike, H. (1974). A new look at the statistics model identification. IEEE Transaction on Automatic Control AC, 19: 716-723.

Al-Quran Surah Yunus, Ayah, 10-19.

Artige, L., \& Nicolini, R. (2006). Evidence on the Determinants of Foreign Direct Investment. The Case of Three European Regions, CREPP Working Paper. 2006/07.

Bartram, M.S., \& Dufey, G. (2001). International Portfolio Investment: Theory, Evidence and Institutional Framework. Thunderbird International Business Review, 39 (5), 535-579.

Beechey, M., Gruen, D., \& Vickery, J. (2000). The efficient market hypothesis: A survey. Research Discussion Paper.

Chapra, M.U. (2001). Islamic Economic Thought and the new Global Economy. Islamic Economic Studies, 9(1).

Gupta, R., \& Guidi, F. (2012). Co integration Relationship and Time Varying Comovements among Indian and Asian Developed Stock Markets. International Review of Financial Analysis, 21, 10-22.

Goetzmann, W. N., \& Valaitis, E. (2006). Simulating Real Estate in the Investment Portfolio: Model Uncertainty and Inflation Hedging. Yale ICF Working Paper, 6-4, March.

Hussin, Y., Yusof, Y., Fidlizan, M., Azila, A., Emilda, H., \& Nur, F. M. (2013). The Integration of Islamic Stock Market: Does a Problem for Investor?. Labuan e-journal of Muamalat and society, 7, 2013, 17-27. 
Kassim. S. H. (2010). Global Financial Crisis and Integration of Islamic Stock Markets in Developed and Developing Countries. Institute of Developing Economies, Japan External Trade Organization, 461.

Kim, E. H., \& Singal, V. (2000). Stock Market Openings: Experience of Emerging Economies. Journal of Business, 73, 25-66.

McAndrews, J., \& Stefanadis, C. (2002). The Consolidation of European Stock Exchanges. Social Science Research Network Current Issues in Economics and Finance, $(8,62)$.

Ming-Yuan Leon, L., (2007), "Volatility States and International Diversification of International Stock Markets", Applied Economics, Vol. 39, Issue 14, pp. 1867-1876.

Pandian, P., \& Jayanthi, Q. (2009). Stock Market Volatility in Indian Stock Exchange. Socio economic voices, May-June 2009.

Pesaran, M. H. (2006). Estimation and inference in large heterogeneous panels with a multifactor error structure. Econometrica, 74(4), 967-1012.

Syllignakis, M.N.\& Kouretas, G.P. (2011). Dynamic Correlation Analysis of Financial Contagion: Evidence from the Central and Eastern European Markets. International Review of Economics \& Finance, 20(4), 717-732.

Yusof, R. M., \& Majid, M. S. A. (2006). Who moves the Malaysian stock market - the US or Japan? Empirical evidence from the pre-, during, and post-1997 Asian financial crisis. Gadjah Mada International Journal of Business, 8, 367-406. 